\title{
Environment and tree size controlling stem sap flux in a perhumid tropical forest of Central Sulawesi, Indonesia
}

\author{
Viviana Horna • Bernhard Schuldt • Sarah Brix • \\ Christoph Leuschner
}

Received: 13 September 2010 / Accepted: 29 January 2011 /Published online: 6 July 2011

(C) The Author(s) 2011. This article is published with open access at Springerlink.com

\begin{abstract}
- Introduction We studied stem sap flux density in seven common tree species in a perhumid tropical rainforest at pre-montane elevation in Sulawesi with the aims (1) to analyse the among-species variation in flow patterns, (2) to search for an assumed convergence in the response to controlling environmental factors, and (3) to investigate the effect of tree size on xylem flux.

- Materials and methods Sap flux density was measured for 20 months in 39 tree individuals of seven species (from six of the most dominant families in the area). Synchronous sap flux density in the outermost xylem differed more than threefold among the species and was highest in the tall Fagaceae Castanopsis acuminatissima. Across the seven species, a tight exponential correlation was found between tree diameter (or tree height) and tree daily water use.

- Results Daily sap flux density correlated better with atmospheric vapour pressure deficit than with shortwave radiation, in spite of the permanently high atmospheric humidity. Soil moisture did not vary significantly and therefore showed no effect on mean daily sap flux density. The hysteresis in the diurnal plot of xylem flux density against vapour pressure deficit or radiation was larger for radiation supporting the close coupling of flux variation to vapour pressure deficit, which exists even in this perhumid climate.

- Conclusion We conclude that the species of this perhumid forest show convergent patterns in the environmental
\end{abstract}

Handling Editor: Gilbert Aussenac

V. Horna $(\bowtie) \cdot$ B. Schuldt $\cdot$ S. Brix $\cdot$ C. Leuschner

Plant Ecology, Albrecht von Haller Institute for Plant Sciences,

University of Göttingen,

Untere Karspüle 2,

37073 Göttingen, Germany

e-mail: vhorna@gwdg.de control of sap flux. Largely different water consumption rates of coexisting trees were mainly caused by differences in tree size and the position of the tree within the canopy. Our extrapolated daily stand transpiration rates are low in comparison to other tropical forests which may be a consequence of the permanently high air humidity.

Keywords Vapour pressure deficit · Soil moisture · Stand transpiration · Tree height · Water consumption · Castanopsis acuminatissima

\section{Introduction}

Tropical moist forests are known for their exuberant species richness which may include a large number of tree functional types with contrasting size, morphology, and ontogeny. Tyree and Ewers (1996) predicted a considerable variation in the diel patterns of stem sap flow in tropical forest trees as a consequence of a large diversity in hydraulic structures. This prediction seems to contradict the conclusion of Meinzer (2003) that tree species from tropical rainforests tend to converge in their patterns of transpiration control and response to drought.

Similar to temperate and boreal forests, atmospheric water vapour saturation deficit $(D)$, solar radiation $(R)$, and soil water content (SWC) are the main environmental factors controlling the transpiration of tropical forests (Meinzer 2003; O’Brien et al. 2004). However, the influence of these three variables may differ among trees of variable sizes and ontogenetic stages. A close correlation has been found in tropical trees between sap flow and stem diameter (Meinzer 2003) and also tree height (Andrade et al. 1998; Becker 1996; Goldstein et al. 1998; Meinzer et al. 2001). Tall trees growing on moist soils exhibit particularly 
high water flow rates, mainly because their larger canopies are exposed to a higher $D$ and elevated radiation fluxes than is the case in smaller trees (Phillips et al. 1999). A sensitive stomatal regulation has been observed in several tropical trees, leading to partial stomatal closure at vapour pressure deficits $>1 \mathrm{kPa}$ (e.g. Fetcher et al. 1994). This may indicate a conservative water use of tropical trees when exposed to short regular, or irregular, dry periods (Granier et al. 1992; O'Brien et al. 2004).

In the perhumid montane rainforests of Central Sulawesi (Indonesia) with about $3,000 \mathrm{~mm}$ of annual precipitation, temperature, solar radiation, rainfall, and vapour pressure deficit vary only slightly throughout the year. Under this perhumid tropical climate, trees have to cope with permanently high humidity and continuous low-driving force for water transport. However, in this environment, dry periods still occur. They are irregular and their intensity and duration are quite unpredictable. Thus, permanent plantadaptive responses to water shortage are not expected in this ecosystem and trees may be very sensitive to drought spells.

In the present study, we examine the sap flux density dynamics of seven common tree species in the tropical premontane rainforest of Central Sulawesi, Indonesia, during a typical humid year and relate them to stand structural properties and climatic variables. The investigation in adult trees should help to improve our understanding of how tropical trees differ in their short-term strategies of controlling water flux in the soil-plant atmosphere continuum and to predict more precisely how tropical forest stands will respond to future climate change.

The investigated species are members of six families with contrasting phylogenetic and biogeographic background. The following questions were addressed, (1) how do coexisting species in a perhumid tropical rainforest differ in their diurnal patterns of sap flow?, (2) does the environmental control of tree sap flux density vary among tree species or is there convergence in the species' response to environmental variation in this perhumid climate?, and (3) how does tree size influence sap flux density?

\section{Materials and methods}

\subsection{Study sites}

The study was carried out at pre-montane elevation $(1,050 \mathrm{~m}$ above sea level) in the tropical rainforest of Pono Valley close to the village of Toro, located on the western boundary of Lore Lindu National Park in Central Sulawesi, Indonesia $\left(01^{\circ} 29.6^{\prime} \mathrm{S}, 120^{\circ} 03.4^{\prime} \mathrm{E}\right)$. The soils of this oldgrown forest developed as Acrisols (Food and Agriculture Organization classification) over metamorphic rocks. The climate of the study area is wet all year long, with a mean annual precipitation of around $3,500 \mathrm{~mm}$. A short dry period with less than $100 \mathrm{~mm}$ rainfall per month usually occurs between July and August. According to the Holdridge classification, the study area falls into the perhumid category (Holdridge et al. 1971). Mean annual air temperature is $20.8^{\circ} \mathrm{C}$.

\subsection{Tree sampling for continuous xylem flux density measurements}

Three permanent plots of $40 \times 40 \mathrm{~m}$ were established in Pono Valley in rainforest areas on level or slightly sloping terrain with a closed canopy and no signs (charcoal, stumps, etc.) of major human impact. Data about tree size and species identity was gathered for all trees with a diameter at breast height (DBH measured at $1.3 \mathrm{~m}$ above the ground) $>10 \mathrm{~cm}$. Trees of $2-10 \mathrm{~cm}$ DBH were investigated in sub-plots of $10 \times 10 \mathrm{~m}$ (Culmsee et al. 2010).

In the three plots, we chose 39 tree individuals of seven common tree species with a DBH of $>10 \mathrm{~cm}$ (Table 1). Tree height $(H)$ was recorded as the distance between the base of the trunk and the top of the crown using a laser sensor (Vertex III Forester, Haglöf, Långsele, Sweden). Basal area was estimated using the DBH and assuming a circular stem cross-sectional area.

Each species was represented by a minimum of three and a maximum of eight tree individuals differing in $H$ and DBH. We focused on trees from different canopy layers and included species from different families with slow-growing mid-story species (e.g. Cryptocarya laevigata, Pouteria firma) as well as fast-growing upper canopy species (e.g. Platea excelsa, Castanopsis acuminatissima). Most of the sampled trees ranged between 10 and $30 \mathrm{~m}$ in height. Some C. acuminatissima and Palaquium luzoniense individuals exceeded $40 \mathrm{~m}$. The vegetation composition of the study area is described in detail in Culmsee et al. (2010).

\subsection{Sapwood area determination}

Sapwood area (SA) was estimated from an empirically developed relationship with DBH and using a staining method (Goldstein et al. 1998; Meinzer et al. 2001) to determine the maximum xylem depth at breast height. For this purpose, we took a separate sample of 57 trees of different species and sizes distributed all over the study area. To avoid injure effect on our measurements, the trees used for the determination of sapwood area were not the same used for continuous monitoring of xylem flux density. During the morning hours (from 8:00-11:00 a.m.), when transpiration rates start rising, a first core was taken at $1.3 \mathrm{~m}$ height with a 5-mm diameter increment borer (Suunto Oy, Vaanta, Finland) to the centre of the trunk. 
Table 1 Biometric characteristics of the seven common tree species investigated for sap flux in Pono Valley, Central Sulawesi

\begin{tabular}{|c|c|c|c|c|c|c|c|}
\hline Species & Family & $n$ & $\mathrm{DBH}(\mathrm{cm})$ & $H(\mathrm{~m})$ & $\mathrm{SA}\left(\mathrm{cm}^{2}\right)$ & $\begin{array}{l}J_{2007} \\
\left(\mathrm{~g} \mathrm{~cm}^{-2} \mathrm{~h}^{-1}\right)\end{array}$ & $\begin{array}{l}J_{2008} \\
\left(\mathrm{~g} \mathrm{~cm}^{-2} \mathrm{~h}^{-1}\right)\end{array}$ \\
\hline V. arborea Buch.-Ham. & Asteraceae & 3 & $20.1-43.0$ & $22.0-28.7$ & $73.6-256.9$ & $1.55 \pm 0.64$ & $1.93 \pm 0.73$ \\
\hline S. apiculata A.W. Benn. & Burseraceae & 5 & $14.6-58.2$ & $17.4-27.6$ & $54.5-589.3$ & $1.74 \pm 0.29$ & $1.43 \pm 0.80$ \\
\hline P. luzoniense (Fern.-Vill.) Vidal & Sapotaceae & 6 & $10.4-95.0$ & $17.6-44.7$ & $43.3-4394.9$ & $2.04 \pm 1.23$ & $2.15 \pm 1.28$ \\
\hline C. laevigata Blume & Lauraceae & 6 & $11.2-27.9$ & $15.4-33.2$ & $45.2-112.7$ & $1.55 \pm 0.41$ & $1.46 \pm 0.83$ \\
\hline P. firma (Miq.) Baehni & Sapotaceae & 5 & $14.7-27.9$ & $14.7-44.3$ & $54.8-745.2$ & $3.05 \pm 1.23$ & $2.68 \pm 1.49$ \\
\hline P. excelsa Bl. var borneensis (Heine) Sleum. & Icacinaceae & 6 & $11.7-45.7$ & $12.3-24.7$ & $46.5-297.8$ & $2.37 \pm 1.23$ & $2.09 \pm 1.18$ \\
\hline C. acuminatissima (Blume) Rheder & Fagaceae & 8 & $11.8-71.4$ & $17.6-43.9$ & $46.8-1211.5$ & $4.08 \pm 1.45$ & $4.70 \pm 1.84$ \\
\hline
\end{tabular}

Stem diameter at breast height (DBH), total tree height $(H)$, sapwood area (SA) as estimated from dye injection experiments and the SA-DBH relationship in the species. $J$ is the mean xylem flux density \pm SD measured in 2007 (May to December) and 2008 (January to December) in the outer $2 \mathrm{~cm}$ of the active xylem by means of the constant heating method after Granier (1985). The number of replicates $(n)$ is the number of trees monitored for xylem sap flux density

Immediately after coring, a $0.1 \%$ indigo carmine solution was injected into the hole and refilled if needed. After 2$4 \mathrm{~h}$, when the dye had been carried upwards with the xylem flux, a second core was taken 3-5 cm above of the injection point. The stained depth of the sapwood was determined visually and was taken as the sapwood depth. Sapwood area was then calculated as the area of the stem ring with a radius equal to the estimated sapwood depth assuming circular sapwood.

\subsection{Xylem flux density and stand transpiration}

We measured xylem sap flux density $\left(J, \mathrm{~g} \mathrm{~cm}^{-2} \mathrm{~h}^{-1}\right)$ in the stem xylem using heat dissipation sensors (Granier 1985). Pairs of 20-mm long and 2-mm wide heating probes were inserted in northern and southern trunk directions into the stem sapwood of each tree. The probes were manufactured according to the original design given by Granier (1985). The upper probe was heated with a constant power of $0.2 \mathrm{~W}$. The temperature difference between the two sensors was recorded with copper-constantan thermocouples placed at the centre of the heating coil. The lower probe was not heated and served as reference for the upper probe. The sensors were installed at $1.30 \mathrm{~m}$ height above the stem base. The distance between the two sensor probes was kept at about $15 \mathrm{~cm}$ to avoid thermal interference. Sap flux velocity was calculated according to the empirical calibration equation given by Granier (1985):

$J_{s}=119 \times K^{1.231}$

where, $K$ is a temperature constant determined as follows

$$
K=\frac{\left(\Delta T_{0}-\Delta T\right)}{\Delta T}
$$

$\Delta T_{0}$ is the maximum temperature difference when sap flow is assumed to be zero and $\Delta \mathrm{T}$ is the actual temperature difference between the two probes. If sapwood depth as estimated from the dyeing experiment was less than the length of the sensors $(2 \mathrm{~cm})$, the flux density data were subject to a correction according to Clearwater et al. (1999). Natural temperature gradients between the probes were recorded during periods when no power was applied to the upper probe; they were negligible due to the closed canopy of this forest.

Mean daily water uptake per tree (DWU, $\mathrm{kg} \mathrm{day}^{-1}$ ) was estimated from the mean daily xylem flux density $\left(J_{d}\right.$, $\mathrm{g} \mathrm{cm}^{-2}$ day $^{-1}$ ) in the outer xylem and the size of the SA of the stem $\left(\mathrm{m}^{2}\right)$. We assumed an exponential decrease in sap flux density from the outer to the inner xylem as was reported in the majority of studies (Becker 1996; James et al. 2003; Motzer et al. 2005; Phillips et al. 1996). The flux density in the outermost $2 \mathrm{~cm}$ were taken as an estimate of maximum xylem flux density, while zero flow was assumed at maximum sapwood depth as determined with the staining method. For each centimetre of sapwood depth, a mean xylem flux density was estimated and it was multiplied by the area of the corresponding sapwood ring to obtain the corresponding flow in this section. Subsequently, the flows of all sapwood rings were added to obtain DWU.

For estimating the daily transpiration rate $E_{\mathrm{c}}$ of the stand $\left(\mathrm{mm}\right.$ day $\left.^{-1}\right)$, we used the inventory data on tree species composition and species abundance of the plots of Culmsee et al. (2010). The six families selected for this study accounted for $58 \%$ of the total stand biomass (referring to trees with $\mathrm{DBH}>2 \mathrm{~cm}$ ); members of the Sapotaceae and Fagaceae, the two most common families, represented $20 \%$ and $24 \%$ of the biomass, respectively. With this sample of families, species and different size classes represented, we assumed that studying a group of 39 representative trees in 
our plots would allow upscaling from mean xylem flux density to stand transpiration using information on stem density and DBH on the plots.

$E_{\mathrm{c}}$ was calculated for $n$ tree height classes as:

$E_{\mathrm{c}}=\frac{1}{n} \sum_{n=1}^{n} J_{d j} \times S A I_{j}$

where, $J_{\mathrm{dj}}$ is the mean daily tree xylem flux density (in $\mathrm{g} \mathrm{H}_{2} \mathrm{O} \mathrm{m}^{-2}$ sapwood day ${ }^{-1}$ ) of the tree height class $j$ and $\mathrm{SAI}_{j}$ is the sapwood area index for the tree height class $j$. $\mathrm{SAI}_{j}\left(\mathrm{~m}^{2} \mathrm{~m}^{-2}\right)$ is the calculated sapwood to ground area ratio for each tree height class. For each height class, we added all individually estimated sapwood areas of the trees belonging to that class and divided it by the plot ground area $\left(1,600 \mathrm{~m}^{2}\right)$. Data from the three experimental plots were pooled when calculating the SAI of a height class.

\subsection{Microclimate measurements}

Above-canopy incident shortwave $R$ was measured with a pyranometer (CS 300, Campbell Scientific, UK), air temperature and relative humidity with a combined temperature and humidity probe (CS 215, Campbell Scientific, UK). Rainfall was recorded to the nearest $0.1 \mathrm{~mm}$ with a tipping bucket rain gauge (ARG100, Campbell Scientific, UK). All sensors were mounted on a $16 \mathrm{~m}$ tall tower located in a large natural forest gap less than hundred metre away from the study plots. All values were registered at 0.5 -h intervals by a Campbell CR10X data logger (Campbell Scientific, UK). Atmospheric $D$ was calculated from air temperature and relative humidity.

Volumetric SWC was recorded half-hourly with time domain reflectometry probes (TDR, Campbell Scientific, UK) in the three stands. At each plot, three soil pits were dug for soil profile description and soil moisture measurements at different depths. TDR probes were inserted at depths of 10, 20, 40, and $75 \mathrm{~cm}$ (Kohler, unpublished data). For our analysis, we used the volumetric soil moisture data from $10 \mathrm{~cm}$ depth where the highest fine root density was found. Deeper in the soil profile, fine root biomass was strongly reduced (Hertel et al. 2009). The sap flux data analysed in this study correspond to the period from May 2007 to December 2008.

\subsection{Data analysis}

Species differences in mean sap flux density were tested by means of ANOVA. To test for the effect of tree size as a covariate in the inter-species comparison of mean sap flux density, we ran an analysis of covariance test using the biometric factor that showed the best correlation to sap flux density.
For every tree, we analysed the diurnal hysteresis in xylem flux density with variation in $D\left(H_{\mathrm{D}}\right)$ and $R\left(H_{\mathrm{R}}\right)$ in 2007. For this calculation, mostly sunny days with less than $2 \mathrm{~mm}$ rainfall were selected ( $n=123$ days). We defined the hysteresis as the difference in $J$ at same $D$ and $R$ values registered either during morning or afternoon hours. The hysteresis area was estimated according to Zeppel et al. (2004) by fitting a polynomial regression to the upper part of the hysteresis loop and another one to the lower part of the loop of the relationship between stem sap flux and $D$ or $R$. The area below the upper polynomial curve minus the area below the lower polynomial curve was our estimated hysteresis area.

Simple regression was conducted to analyse the relationship between sap flux density and environmental parameters $(D, R$, and $\mathrm{SWC})$ for each species. Multiple regression analysis was used to compare the effects of $D$ and $R$ as controlling environmental factors and tree height and DBH as controlling biometric parameters of daily stem sap flow. These calculations were conducted with the SAS System for Windows 9.1 (SAS Institute, Cary, NC, USA) and Sigma Plot 10.0 software (Systat software, Inc.).

\section{Results}

\subsection{Climate}

During the study period from July 2007 to December 2008, volumetric soil moisture at $10 \mathrm{~cm}$ depth varied between $41.2 \%$ and $52.1 \%$. Soil water content decreased to a minimum of 41 vol.\% at the end of February 2008 (Fig. 1). The mean atmospheric vapour pressure deficit during this period was $0.33 \mathrm{kPa}$ with a maximum of $2.72 \mathrm{kPa}$ at the end of September 2007. Total precipitation was $1,375 \mathrm{~mm}$ between July and December 2007 and a total of $2,901 \mathrm{~mm}$ for 2008. In July 2007 and in January and December 2008, less than $100 \mathrm{~mm}$ of rain fell in each month. Highest monthly precipitation was registered in March $2008(541 \mathrm{~mm})$. Global radiation was highest at the end of January and at the end of December 2008 (23.05 and 23.36 $\mathrm{MJ} \mathrm{m}^{-2}$ day $^{-1}$, respectively).

\subsection{Sapwood area}

The 39 investigated trees varied considerably in size. Santiria apiculata, Vernonia arborea, C. laevigata, and P. excelsa were mainly represented by mid to lower canopy individuals while P. luzoniense, P. firma, and C. acuminatissima were present with trees of all size classes, including emergent trees of the uppermost canopy (Table 1). Because the dyeing experiment showed that the sapwood depth of the studied trees exceeded the length of the xylem flux density sensors 
Fig. 1 Daily totals of global radiation (top), daily mean air temperature and mean daily vapour pressure deficit (centre), and daily precipitation and mean volumetric soil water content (bottom) during the measurement interval from July 2007 to December 2008 in Pono Valley in Central Sulawesi, Indonesia. Air temperature, radiation, and precipitation were measured on a $16 \mathrm{~m}$ tall tower located in a forest gap. Volumetric soil water content data are means of three plots with three measurement locations each (soil depth of $10 \mathrm{~cm}$ ). Due to malfunction of the radiation sensor, data of $R$ is missing for several days at the end of November 2007
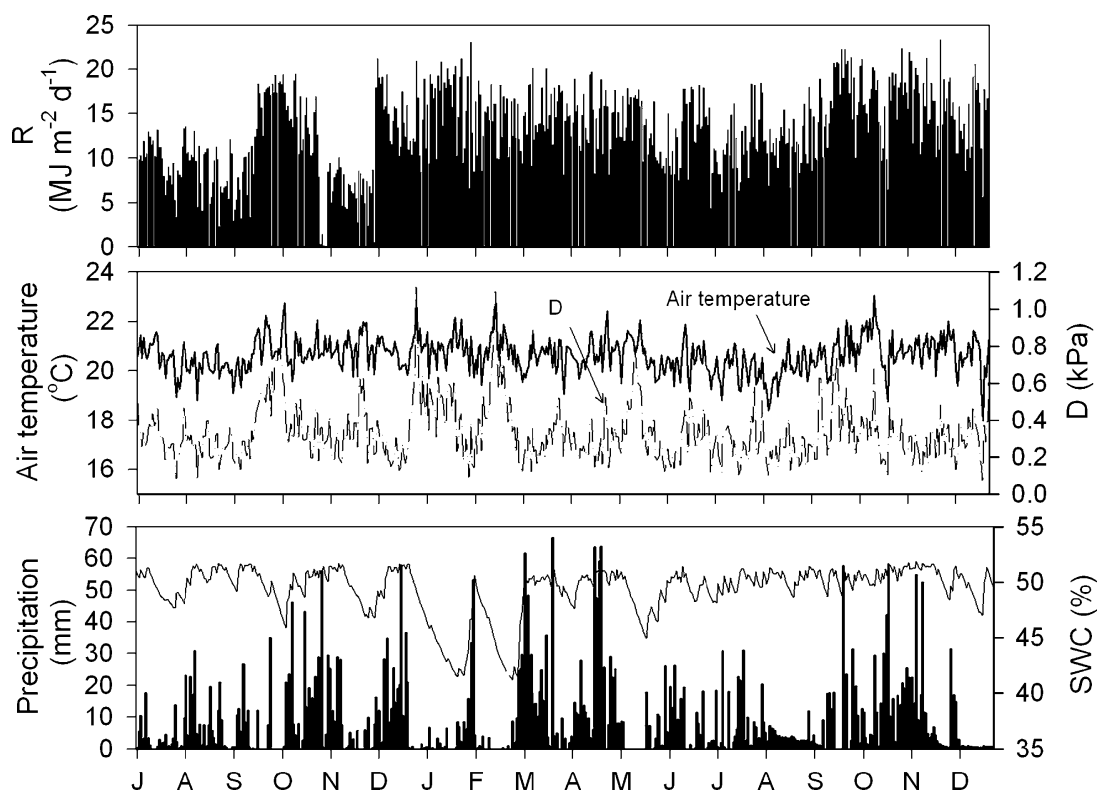

$(2 \mathrm{~cm})$ in all trees, corrections according to Clearwater et al. (1999) were not applied to our sap flux data.

We found a significant positive correlation $(P=0.0001$, $R^{2}=0.72$ ) between $\mathrm{DBH}$ and the estimated sapwood area across the 57 trees from at least 13 species investigated by dyeing (Fig. 2). Five individuals from the Myrtaceae family could not be identified to the species level, but three morpho-species were distinguished.

3.3 Sap flow of the seven tree species: response to climatic factors and tree size

Mean xylem flux density was largest in $C$. acuminatissima (4.08 $\mathrm{g} \mathrm{cm}^{-2} \mathrm{~h}^{-1}$ in 2007 and $4.71 \mathrm{gcm}^{-2} \mathrm{~h}^{-1}$ in 2008$)$ and smallest in $V$. arborea $\left(1.55 \mathrm{~g} \mathrm{~cm}^{-2} \mathrm{~h}^{-1}\right.$, in 2007) and in $S$. apiculata $\left(1.43 \mathrm{~g} \mathrm{~cm}^{-2} \mathrm{~h}^{-1}\right.$, in 2008; Table 1). The mean xylem flow measured between July and December 2007 was larger than the mean flow recorded in the full year of 2008 in the case of S. apiculata, P. firma, and P. excelsa, but smaller for the other four species. However, the differences between the mean xylem flux density rates of 2007 and 2008 (Table 1) were not significant.

Maximum $J$ coincided with, or occurred shortly after, the daily maximum of irradiance but happened earlier than the maximum of $D$ in all species (Fig. 3, left panels). The hysteresis loop of the relationship between sap flow and $D$ showed a clockwise rotation for all species (Fig. 3), that is, xylem flow increased rapidly with $D$ in the morning, while in the afternoon, $D$ decrease preceded the decline in xylem flow. The relationship between xylem flow and solar radiation showed an opposite direction (counterclockwise rotation) for all species (Fig. 3, right panels). The rates of
Fig. 2 Relationship between DBH and sapwood area (SA) across 57 trees of the perhumid forest of Pono Valley, Central Sulawesi, Indonesia. The trees belong to 10 species plus at least three morpho-species from the Myrtaceae family. The solid line is the line of the regression described by a polynomial function of the form: $\log$ $(\mathrm{SA})=b_{0}+b_{1} \mathrm{DBH}$

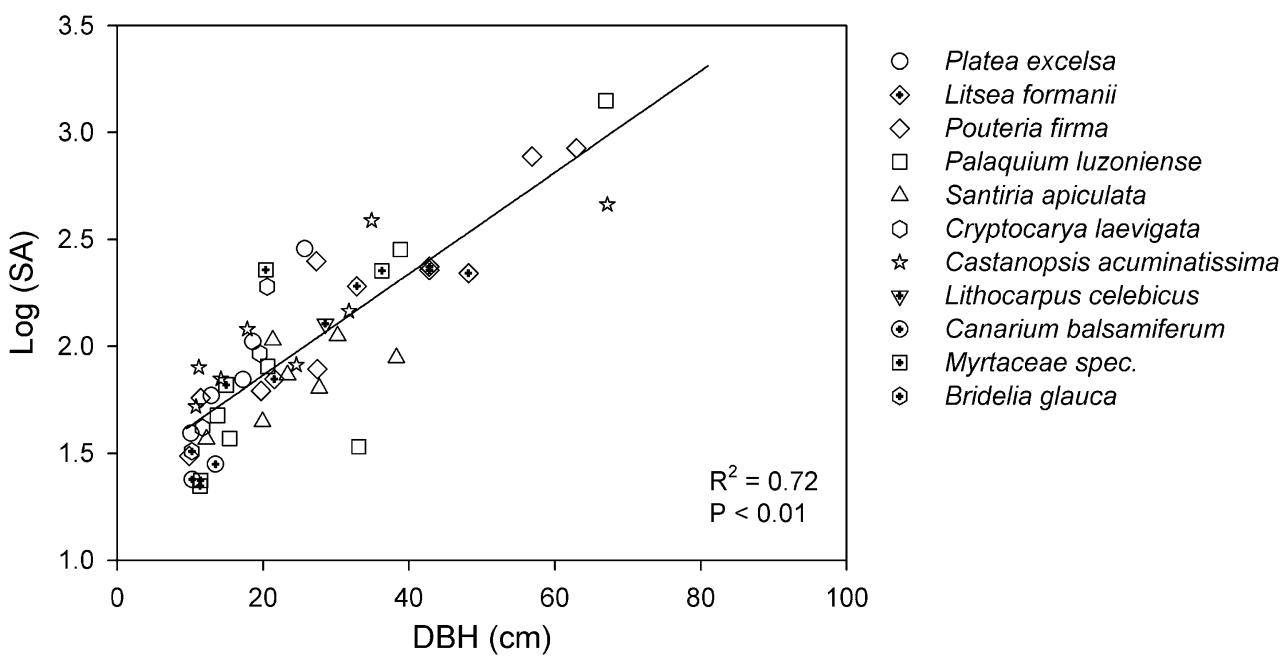



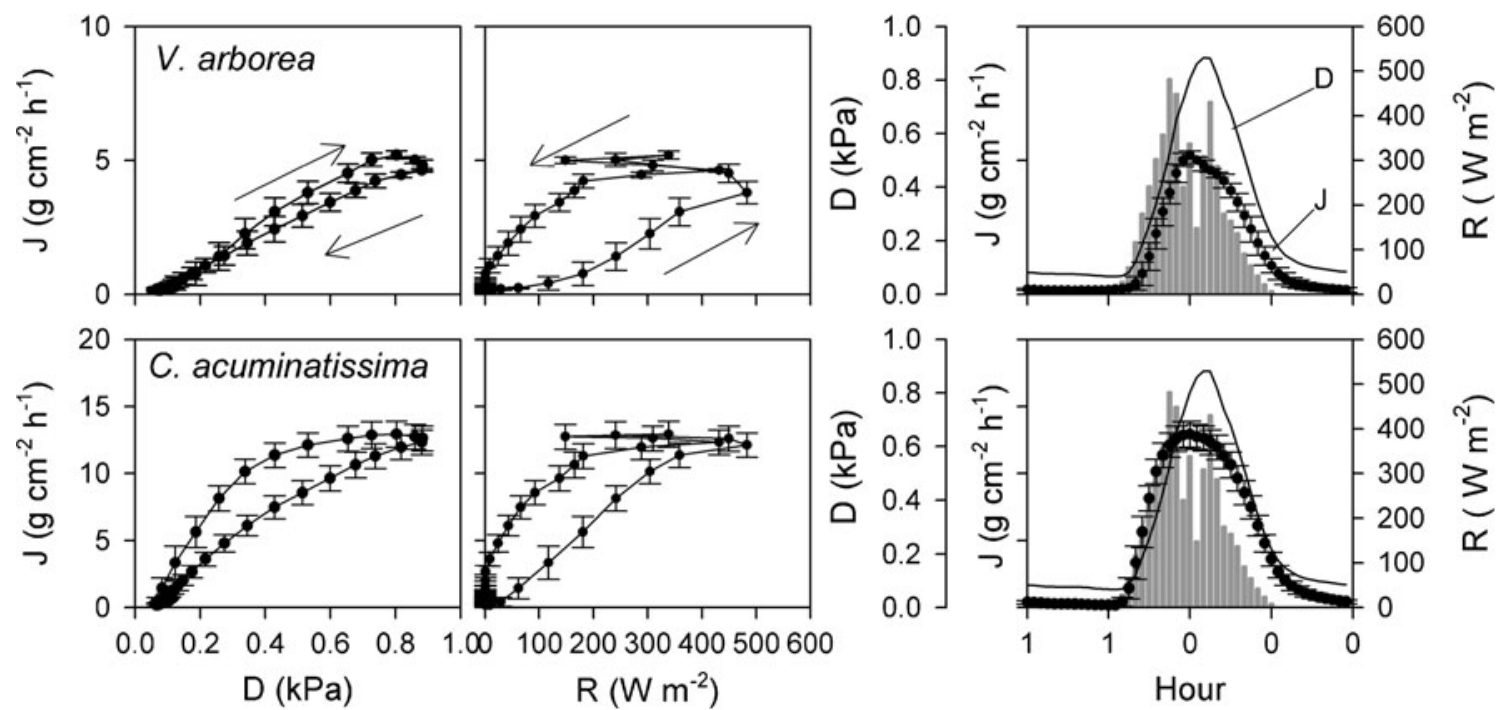

Fig. 3 Diurnal relationship between xylem flux density $(J$, $\left.\mathrm{g} \mathrm{cm}^{-2} \mathrm{~h}^{-1}\right)$ and vapour pressure deficit $(\mathrm{kPa})$ or solar radiation $\left(\mathrm{W} \mathrm{m}^{-2}\right.$ ) for two representative species with different mean xylem flux density. Bars indicate the standard deviation. Arrows give the direction

xylem flux density in the afternoon were larger than the morning values at a given $R$ value. Plotting the estimated area of the hysteresis loop from the relationship of xylem flow with $D$ and $R$ against tree height yielded a significant positive relationship in both cases (Fig. 4), whereas no significant increase of the hysteresis area was found with DBH (data not shown).

Across the species, we found highly significant linear correlations between log DWU and DBH or tree height (Fig. 5), i.e. an exponential increase of tree sap flux with tree size. During both years, the correlation with DBH was slightly better than with tree height. of the diurnal course from morning to afternoon. In the right panels: $D$ (solid line), $R$ (grey bars), and mean $J \pm \mathrm{SE}$ (black points with bars). Note the different scaling for $J$ between the upper four and the lower three species. This also applies to the right panels

The results of the multiple regression analysis showed that the daily xylem flow rates of the seven species were explicable to a high degree by a combination of tree size (DBH and $H$ ) and environmental factors $(D, R$, and SWC) with the models reaching correlation coefficients between $R^{2}=0.39$ for $C$. acuminatissima and $R^{2}=0.84$ for $P$. firma (Table 2). In the backward selection procedure, the variables tree height and soil water content were removed in the case of $C$. acuminatissima and $P$. luzoniense, respectively. Mean vapour pressure deficit and stem DBH were the variables that explained most of the variation in daily xylem flow. Their importance varied among the seven species.

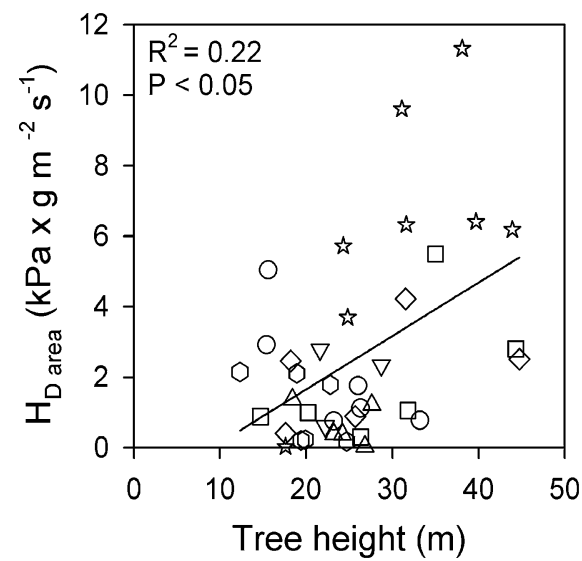

Fig. 4 Relationship between tree height and the estimated mean area of the hysteresis in the relationship between daily xylem flow and vapour pressure deficit $\left(H_{\mathrm{D}}\right)$ or solar radiation $\left(H_{\mathrm{R}}\right)$. Data correspond to the study period between July and December 2007. Symbols stand

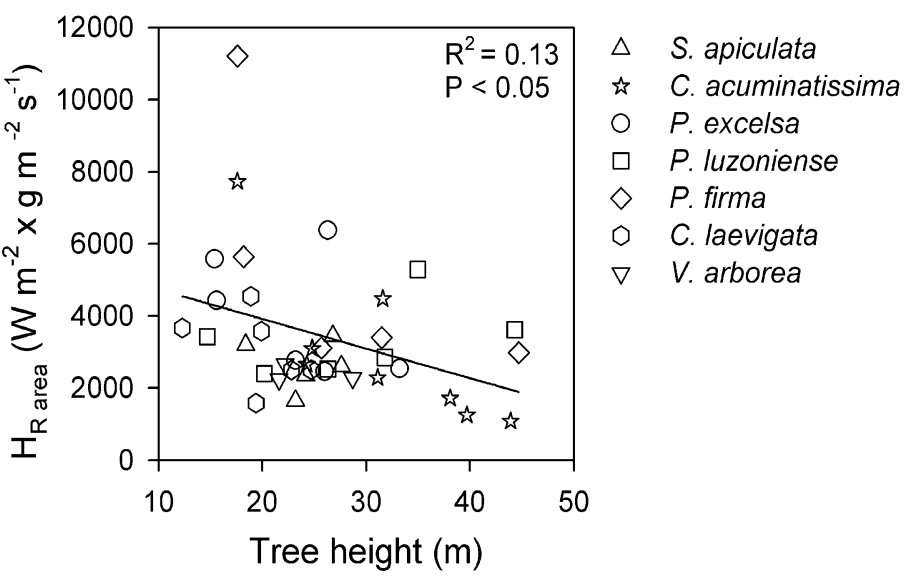

for the seven species investigated. Refer to Table 1 for information about tree species and number of trees measured. The solid line is the line of the linear regression 


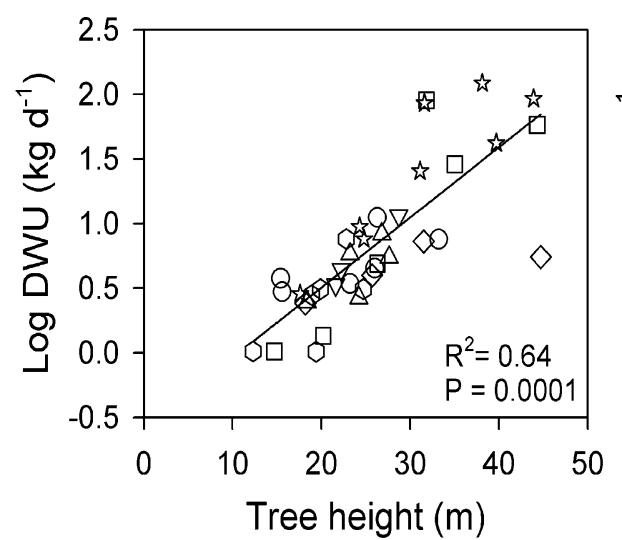

Fig. 5 Relationship between tree size, expressed in terms of tree height $(H, \mathrm{~m})$ or DBH $(\mathrm{cm})$, and mean tree daily water use per tree (DWU, $\mathrm{kg} \mathrm{day}^{-1}$ ) across 39 trees from seven species in the studied stand. Data correspond to the whole year 2008. The solid line is the

\subsection{Stand transpiration}

The mean sapwood area summed over all trees with DBH $>10 \mathrm{~cm}$ was $8.6 \pm 2.1 \mathrm{~m}^{2} \mathrm{ha}^{-1}$. The largest part of the stand sapwood area was contributed by tall trees $(H>30 \mathrm{~m}, 6.2 \pm$ $\left.1.4 \mathrm{~m}^{2} \mathrm{ha}^{-1}\right)$. Correspondingly, the up-scaled stand transpiration rate per tree height class demonstrated the major contribution of tall trees ( $H>30 \mathrm{~m}$, Fig. 6) that used up to 10 times more water than all other tree height classes. Estimated stand transpiration during 2008 varied from 0.09 to $1.05 \mathrm{~mm} \mathrm{day}^{-1}$ resulting in a mean annual total of $252.6 \mathrm{~mm}$.

Across all tree height classes, the transpiration rates showed a strong and highly significant dependence on $D_{\text {mean }}$ and $R$, and a less tight, and in some cases negative, correlation with SWC (Fig. 7, Table 3). The correlation between transpiration rates and mean vapour pressure linear regression line. Different symbols are used for the seven species studied. The regression line between DWU and tree height has the equation, $\log (\mathrm{DWU})=-0.582+0.054 \mathrm{H}$; and for $\mathrm{DWU}$ versus $\mathrm{DBH}$, $\log (\mathrm{DWU})=0.095+0.024 \mathrm{DBH}$

deficit revealed highest correlation coefficients for the smaller trees $\left(R^{2}=0.86\right.$ for the tree height class $\left.<10 \mathrm{~m}\right)$ and the smallest for the tallest trees $\left(R^{2}=0.69\right.$ for trees $>30 \mathrm{~m}$ ). The relationship between $E$ and maximum values of $D$ resulted in much lower $R^{2}$ values than with $D_{\text {mean }}$ (data not shown).

\section{Discussion}

\subsection{Sapwood area}

In the Sulawesi forest, the size of the active sapwood area in the stem cross-section, as calculated from the empirically established relationship with DBH, was smaller than in many other tropical forests. For example, Motzer et al. (2005) reported much larger sapwood areas for tropical

Table 2 Equation parameters and variance explained by five environmental and tree size variables regressed on mean daily xylem flux density $\left(J_{\mathrm{d}}, \mathrm{g} \mathrm{cm}^{-2} \mathrm{day}^{-1}\right)$ for the seven tree species investigated

\begin{tabular}{|c|c|c|c|c|c|c|c|c|c|c|c|c|}
\hline \multirow[t]{2}{*}{ Species } & \multicolumn{6}{|l|}{$R^{2}$} & \multicolumn{6}{|c|}{ Parameter estimates } \\
\hline & Model & DBH & $H$ & $D_{\text {mean }}$ & $R$ & SWC & $b_{0}$ & $b_{1}$ & $b_{2}$ & $b_{3}$ & $b_{4}$ & $b_{5}$ \\
\hline V. arborea & 0.59 & 0.13 & 0.008 & 0.32 & 0.13 & 0.004 & -22.57 & -0.454 & 0.585 & 40.965 & 0.003 & 0.52 \\
\hline S. apiculata & 0.53 & 0.12 & 0.008 & 0.34 & 0.04 & 0.013 & 51.47 & -0.507 & 0.595 & 44.547 & 0.003 & -1.025 \\
\hline P. luzoniense & 0.64 & 0.34 & 0.130 & 0.16 & 0.01 & n.s. & -42.13 & 0.141 & 1.770 & 66.293 & 0.002 & n.s. \\
\hline C. laevigata & 0.82 & 0.39 & 0.013 & 0.36 & 0.04 & 0.007 & -74.93 & 2.654 & -0.829 & 68.278 & 0.002 & 0.792 \\
\hline P. firma & 0.84 & 0.59 & 0.013 & 0.18 & 0.05 & 0.001 & -52.09 & 2.247 & -1.353 & 72.609 & 0.004 & 0.627 \\
\hline P. excelsa & 0.54 & 0.19 & 0.032 & 0.28 & 0.02 & 0.006 & 15.30 & 0.613 & -3.288 & 89.333 & 0.002 & 0.986 \\
\hline C. acuminatissima & 0.39 & 0.18 & n.s. & 0.13 & 0.05 & 0.022 & -142.43 & 0.810 & n.s. & 91.029 & 0.005 & 3.067 \\
\hline
\end{tabular}

The multiple regression analyses followed the general model: $J_{\mathrm{d}}=b_{0}+b_{1} \mathrm{DBH}+b_{2} H+b_{3} D+b_{4} R+b_{5} \mathrm{SWC}$. Data used in the analysis are from 2008 . The coefficient of determination $\left(R^{2}\right)$ for the general regression model is also presented. Non-significant variables (n.s.) were removed from the initial model. Only variables significant at the 0.05 level were left in the model 


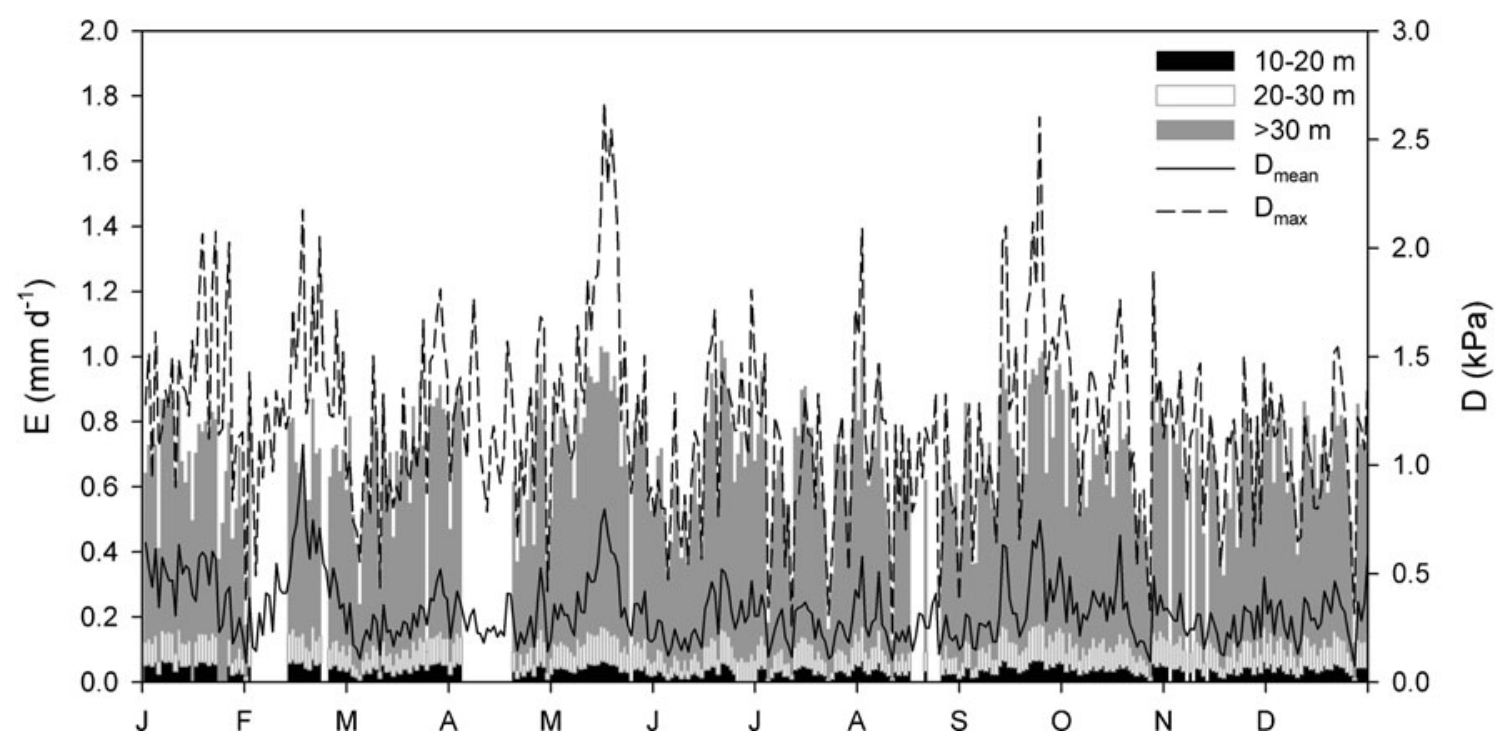

Fig. 6 Annual course of estimated daily transpiration rates for 2008 $\left(\mathrm{mm}\right.$ day $\left.^{-1}\right)$ per tree height class in the perhumid forest of Pono Valley, Central Sulawesi, Indonesia. The black, white, and grey bars stand for three tree height classes: the stand total of $E$ is the top of the grey bars. Transpiration rates of trees with a diameter smaller than $10 \mathrm{~cm}$ were

montane forests in Ecuador as did Meinzer et al. (2001) for tropical lowland forests in Panama. In contrast, Becker (1996), using xylem flux density sensors installed at different depths, also found relatively small sapwood depths in Bornean tree species which are comparable to our data. Similarly, Parolin et al. (2008), using the dyeing method as very low and not visible at the scale of this figure; for this reason, they are not included. The solid line indicates mean values of vapour pressure deficit $(\mathrm{kPa})$ and the broken line gives the daily maximum vapour pressure deficit $(\mathrm{kPa})$

in our study, reported from flooded Amazonian trees a relatively small fraction of the total stem basal area to be sapwood (31-49\%). Granier et al. (1996) observed a constant sapwood thickness (ranging between 3.5 and $5.0 \mathrm{~cm}$ ) in trees from French Guiana. According to the cited studies, the sapwood area in tropical trees shows a
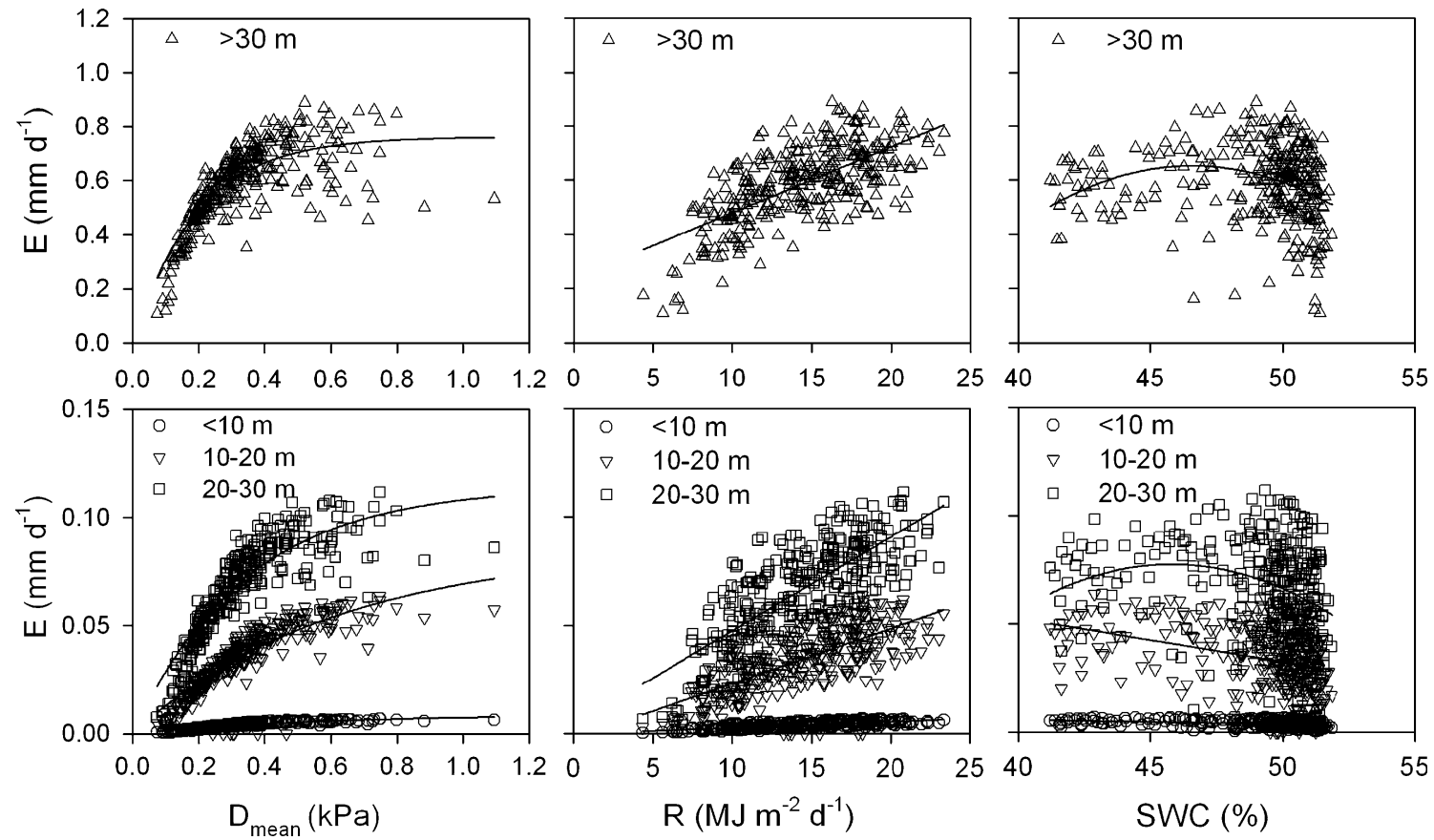

Fig. 7 Relationship between estimated daily transpiration rate in 2008 $\left(\mathrm{mm} \mathrm{day}{ }^{-1}\right)$ per tree height class and the environmental variables centre), and volumetric soil water content (SWC in \%, right). The correlation coefficients and parameter estimates are listed in Table 3 
Table 3 Parameter estimates and coefficients of determination $\left(R^{2}\right)$ of the relationship between environmental variables and daily transpiration rate $\left(E, \mathrm{~mm} \mathrm{day}^{-1}\right)$ per tree height class during 2008

\begin{tabular}{|c|c|c|c|c|c|c|c|c|c|c|c|c|c|}
\hline \multirow[t]{4}{*}{ Tree height class $(\mathrm{m})$} & \multicolumn{4}{|c|}{$E$ vs. $D_{\text {mean }}$} & \multicolumn{4}{|l|}{$E$ vs. $R$} & \multicolumn{5}{|c|}{$E$ vs. SWC } \\
\hline & \multicolumn{4}{|c|}{$E=a\left(1-\exp \left(-\mathrm{bD}_{\text {mean }}\right)\right)$} & \multicolumn{4}{|c|}{$E=E=b_{0}+b_{1} R$} & \multirow{2}{*}{\multicolumn{5}{|c|}{$\begin{array}{l}E=b_{0}+b_{1} \mathrm{SWC} \\
E=b_{0}+b_{1} \mathrm{SWC}+b_{2} \mathrm{SWC}^{2}\end{array}$}} \\
\hline & \multirow[b]{2}{*}{$a$} & \multirow[b]{2}{*}{$b$} & \multirow[b]{2}{*}{$R^{2}$} & \multirow[b]{2}{*}{$P$} & \multirow[b]{2}{*}{$b_{0}$} & \multirow[b]{2}{*}{$b_{1}$} & \multirow[b]{2}{*}{$R^{2}$} & \multirow[b]{2}{*}{$P$} & & & & & \\
\hline & & & & & & & & & $b_{0}$ & $b_{1}$ & $b_{2}$ & $R^{2}$ & $P$ \\
\hline$<10$ & 0.009 & 1.762 & 0.86 & $<0.001$ & -0.0003 & 0.0003 & 0.55 & $<0.001$ & 0.014 & -0.0002 & - & 0.12 & $<0.001$ \\
\hline $10-20$ & 0.086 & 1.629 & 0.75 & $<0.001$ & -0.0024 & 0.0025 & 0.47 & $<0.001$ & 0.133 & -0.0002 & - & 0.12 & $<0.001$ \\
\hline $20-30$ & 0.114 & 2.894 & 0.80 & $<0.001$ & 0.0039 & 0.0043 & 0.59 & $<0.001$ & -1.265 & 0.0586 & -0.0006 & 0.07 & $<0.001$ \\
\hline$>30$ & 0.763 & 5.159 & 0.69 & $<0.001$ & 0.2364 & 0.0243 & 0.45 & $<0.001$ & -10.543 & 0.4807 & -0.0052 & 0.07 & $<0.001$ \\
\hline
\end{tabular}

The relationship between $E$ and vapour pressure deficit $\left(D_{\text {mean }}, \mathrm{kPa}\right)$ followed an exponential form for all tree height classes. The relationship between $E$ and solar radiation $\left(R, \mathrm{MJ} \mathrm{m}^{-2}\right.$ day $\left.^{-1}\right)$ was better fitted to a first-order polynomial in all tree height classes. The relationship between $E$ and soil water content (SWC, \%) was better explained by a first-order polynomial in the smaller tree height classes and by a second-order polynomial in the taller trees

considerable variation across species and forest stands, and it remains unclear what factors are controlling this variation. Our data fall within the lower range of sapwood depth data reported for tropical trees. Own measurements of xylem flux density profiles in the xylem confirmed the small sapwood depth found by dyeing in Sulawesi

4.2 Among-species variation in xylem flux density and daily water consumption

The xylem flux density in the outermost xylem differed up to threefold among the seven synchronously measured species which mainly reflects contrasts in tree size and canopy position, but may also be due to species differences in hydraulic architecture and other traits influencing water consumption. The recorded mean sap flux densities of the seven tree species in Sulawesi $\left(1.43-3.04 \mathrm{~g} \mathrm{~cm}^{-2} \mathrm{~h}^{-1}\right.$ for all species excluding C. acuminatissima, $4.71 \mathrm{~g} \mathrm{~cm}^{-2} \mathrm{~h}^{-1}$ for this species of the Fagaceae) are below the lower range of values published for tropical forest trees that mostly range between 5 and $50 \mathrm{~g} \mathrm{~cm}^{-2} \mathrm{~h}^{-1}$ (Granier et al. 1996; Meinzer et al. 2001; Dünisch and Morais 2002). Peak xylem flux densities reported for tropical trees reach up to $70 \mathrm{~g} \mathrm{~cm}^{-2} \mathrm{~h}^{-1}$ (Becker 1996; O'Brien et al. 2004), while in this study large C. acuminatissima trees showed maximum xylem flux densities of only $15 \mathrm{~g} \mathrm{~cm}^{-2} \mathrm{~h}^{-1}$. We assume that one reason for the rather low xylem flux densities in the Sulawesi stand is the continuously high air humidity in the study region, rarely exceeding a $D$ of $1 \mathrm{kPa}$. By monitoring canopy surface wetness during a period of 3 months, Dietz et al. (2007) found leaf wetness to be an important factor in the montane forest of Sulawesi. On average, the upper canopy was wet for $25-30 \%$ of the time, while under rain conditions surface wetness was recorded for even $45-55 \%$ of the time. Individual periods of leaf wetness lasted for 16 to more than $22 \mathrm{~h}$ after a rainfall event, depending on the position in the canopy. As expected, very low atmospheric saturation deficits were measured during periods of leaf wetness that must translate into very low or zero transpiration rates.

Another reason for low xylem flux density values can be measuring errors due to gradually decreasing contact between the sensor probe and the xylem tissue. We are confident that this source of error can be excluded in our study because sensors were replaced when significant changes in the sensor signal were detected.

When upscaled to whole-tree water use, the mean rates per tree revealed a similarly large range of variation among the 39 individuals of the seven species studied as did flux density. The maximum rate of water use $\left(132 \mathrm{~kg} \mathrm{day}^{-1}\right)$ was calculated for a large $C$. acuminatissima tree $(\mathrm{DBH}=$ $71.4 \mathrm{~cm}$ ), the smallest rate was recorded with $1 \mathrm{~kg} \mathrm{day}^{-1}$ in a small sub-canopy $C$. laevigata individual with a DBH of $11.9 \mathrm{~cm}$. The estimated monthly stand water use for 2008 was calculated at $31.5 \mathrm{~mm}$. Jordan and Kline (1977), using radioactive and stable isotopes, reported a much higher maximum daily water use of $1,180 \mathrm{~kg} \mathrm{day}^{-1}$ in a large tree of the Amazonian species Eperua purpurea ( $\mathrm{SA}=$ $0.152 \mathrm{~m}^{2}$ ). Maximum rates of daily water consumption for other tropical moist forest species using the same methodology as here varied between $24 \mathrm{~kg}^{\text {day }}{ }^{-1}$ for Cassipourea guianensis $\left(\mathrm{SA}=0.019 \mathrm{~m}^{2}\right)$ in French Guiana (Granier et al. 1996) and $750 \mathrm{~kg} \mathrm{day}^{-1}$ for Anacardiun excelsum $\left(\mathrm{SA}=0.660 \mathrm{~m}^{2}\right)$ in Panama (Meinzer et al. 2003).

We found a tight relation between tree daily water use and tree height in the form of an exponential increase across the seven common tree species of this perhumid tropical rainforest. Various other authors have also reported a positive tree size-water consumption relationship for tropical species referring either to tree height or DBH (e.g. Andrade et al. 1998, with tree height; Meinzer et al. 2005, 
with DBH). As mentioned earlier, the exposure to a higher $D$ and greater radiation load should increase water consumption with increasing canopy height and, thus, largely explains the over-proportional contribution of tall trees to the stand transpiration in this forest.

Becker (1996) provided one of the few measurements of stand transpiration for tropical forests in Southeast Asia aside from this study. Water use calculated from the mean sap flow of trees with diameters of at least $20 \mathrm{~cm}$ varied between 1.43 and $1.17 \mathrm{~mm} \mathrm{day}^{-1}$ for dipterocarp and heath forests, respectively, in Becker's (1996) study, which is only slightly higher than in the Sulawesi stand. However, the pre-montane Sulawesi stand with abundant Fagaceae is only partly comparable to the tall lowland dipterocarp forest site of Becker (1996; tree height 45 vs. 50-60 m). Estimates of stand transpiration in a tropical lowland rainforest of French Guiana yielded higher transpiration rates ranging between 2.3 and $4.5 \mathrm{~mm} \mathrm{day}^{-1}$ (Granier et al. 1996). This forest had a sapwood area of $11.4-13.6 \mathrm{~m}^{2} \mathrm{ha}^{-1}$ while the Sulawesi stand reached only $9.1 \mathrm{~m}^{2} \mathrm{ha}^{-1}$. Moreover, $D$ averaged at daily values of $2.5 \mathrm{kPa}$ in the lowland forest, more than twice the mean daily saturation deficit registered in our study area.

The remarkably low transpiration rate in this perhumid forest accounts for only about $9 \%$ of annual precipitation, which might indicate large amounts of deep seepage and runoff. However, canopy interception seems to consume a large proportion of rainfall; Dietz et al. (2006) measured median interception rates of $30 \%$, and peak rates of $53 \%$, in a nearby natural forest, which indicates that roughly $60 \%$ of annual precipitation (c. 3,500 $\mathrm{mm}$ ) must have gone to deep drainage and runoff. It should be noted that, in this estimate, the contribution of understory vegetation to transpiration and interception is missing, but these terms are assumed to be small under the prevalent humid conditions inside the forest.

Effects of radial variation in the rate of xylem flux density were not investigated within the scope of this study. With the $2-\mathrm{cm}$ probes used in this study, we covered only the outer xylem but may have missed areas of low flux density deeper in the wood of large trees. We assumed that $J$ decreases exponentially toward the inner sapwood as has been found in an earlier preliminary study on radial flux profiles in stems of $C$. acuminatissima, P. luzoniense, $S$. apiculata, and P. excelsa in this stand (data not shown). In the case of $P$. excelsa, the area of maximum xylem flux density was wider than in the other species. The radial flux profiles also confirmed that the region of maximum xylem flux density is indeed located in the outermost sapwood which is in agreement with results obtained by Becker (1996), Phillips et al. (1996), and Jimenez et al. (2000).

Suppressed understory trees may, however, show deviating radial flux profiles. Jimenez et al. (2000) observed that suppressed trees were characterised by a uniform xylem flux density rate across the active sapwood. Thus, it may well be that our calculated water consumption rates somewhat underestimate the true flow in suppressed trees by assuming an exponential decrease in xylem flux density towards the inner sapwood. However, the contribution of these trees to total stand transpiration should be $<10 \%$, since sub-canopy trees accounted for only $15 \%$ or less of stand basal and sapwood area and the maximum xylem flux density rates in these trees was significantly smaller than that of large canopy trees. Clearly, a correction of the estimated water consumption data using well-defined xylem flux density profiles from a larger number of sample trees as suggested by Jimenez et al. (2000) would not only reduce the error in flux estimates at the tree and stand levels, but should also give a clearer picture of the relationship between $J$ and tree size.

\subsection{Environmental control of tree sap flux density}

We monitored sap flux during an 18-month interval with the climatic conditions in this period being typical for the region. In the perhumid forest of Sulawesi, the influence of vapour pressure deficit and radiation on flux density was much less important at the species level than in other studies on tropical or temperate trees. We found $18-45 \%$ of the variation in sap flux density being explained by a combination of $D$ and $R$. In a Panamanian forest, Phillips et al. (1999) found that, on a daily basis, sap flow in lianas and trees was more closely related to $D$ than to $R$, while during the diurnal course, tree sap flow was most tightly associated with $R$. The authors attempted to explain the discrepancy between the temporal scales by the assumption that $R$ should control the diurnal variation in xylem flux through stomatal regulation, while $D$ is determining the magnitude of daily water uptake.

At the stand level and across tree height classes, the relationship between daily canopy transpiration and atmospheric evaporative demand was much tighter with correlation coefficients of 0.86 for the lower tree height class. Tree species present with individuals mainly in the lower to middle canopy exhibited a higher correlation coefficient with $D$ than species with trees reaching more than $40 \mathrm{~m}$ in height where the correlation coefficient for the relation of flux to tree size (DBH) was particularly high. The phenomenon of remarkably small correlation coefficients of $J$ with $D$ in tall trees (C. acuminatissima, $P$. firma, and P. luzoniense) as compared to smaller trees in lower canopy strata may have its explanation in a greater water storage in the stems of taller trees. Phillips et al. (2003) observed that larger trees had significantly greater ratios of sapwood volume to crown leaf area than smaller trees and a greater water storage capacity in relation to the 
amount of water used. However, Meinzer et al. (2004) reported that stored water contributed at a constant rate of about $10 \%$ to the daily water budget of four tropical angiosperm species, regardless of tree size.

Different amounts of water stored in the trunk should also influence the degree of hysteresis in the relationship of $D$ and $R$ to flux density. The degree of hysteresis was larger in the relationship between xylem flux density and solar radiation than with $D$, indicating a closer coupling between $J$ and the atmospheric evaporative demand than with radiation in all seven species. Lower $J$ rates at a given $D$ in the afternoon may result from increased stomatal sensitivity to $D$, lowered leaf conductances due to reduced light levels, or a decrease in leaf water potential in the afternoon, or alternatively diurnal plant internal metabolic rhythms (O'Brien et al. 2004; Zeppel et al. 2004). Increasing hysteresis in the $J / R$ relationship with decreasing tree height seems to indicate an increasing time lag in the response of xylem flux to light variation when trees are smaller (Fig. 3). Such an effect was also observed by O'Brien et al. (2004) and was explained by stem water storage, a particularly slow stomatal response to light in the understory, or gas phase diffusion limitation due to leaf wetness. As mentioned before, the occurrence of leaf wetness inside the forest canopy is indeed a frequent event at our study site.

Among the species investigated in Sulawesi, $C$. acuminatissima showed the largest hysteresis area in the $J / D$ relationship and hysteresis decreased significantly with decreasing tree height in our sample. In taller trees, both larger water storage in the trunk and probably a higher stomatal sensitivity to $D$ are likely explanations of larger hysteresis. Trees of C. acuminatissima are reaching more than $50 \mathrm{~m}$ in height and DBH values of $>70 \mathrm{~cm}$ on the plots which points at a presumably high storage capacity for water in the trunk.

The position of the air humidity sensor is also important. We used $D$ values measured in a forest gap. These data should reflect the microclimatic conditions in the upper canopy while $D$ was certainly smaller inside the forest. Gaps and forest interior typically differ in the magnitude of $D$ experienced during the daylight hours but not with respect to the shape of the diurnal course of $D$. The smaller daily amplitude of $D$ inside the stand might have resulted in a stronger correlation between sap flux and $D$ than was registered in this study with $D$ measured in a gap.

The clockwise rotation in the response curve to $D$ and counterclockwise rotation in the case of $R$ has been previously observed by O'Brien et al. (2004) in tropical trees in Costa Rica, and by Kelliher et al. (1992) and Zeppel et al. (2004) in temperate tree species. This reverse pattern has been explained by Zeppel et al. (2004) by differences in the timing of maximum $D$ and $R$. Because $D$ peaks later than $R$, the vapour pressure deficit is at a given value of $R$ in the morning smaller than in the afternoon. The larger hysteresis loop in the radiation curve than in the $D$ curve may be explained by the larger relative difference in $R$ between morning and afternoon hours while diel changes in $D$ are dampened due to prevailing humid conditions in the study area. In a Eucalyptus stand in a much drier climate in Australia, the proportional variation between morning and afternoon $D$ values was larger than the variation in radiation (Zeppel et al. 2004).

With coefficients of determination mostly below 0.1 , the influence of soil moisture on the variation in sap flow was the smallest of all three environmental variables included in this study. We believe that this is mainly a consequence of the high soil water content that prevailed throughout the period of investigation and the overall perhumid climate of the study area. Because of continuously high precipitation in the area, soil water content measured in the upper $10 \mathrm{~cm}$ was all the time close to field capacity (van Straaten 2010), even during January and February 2008, when the lowest soil moisture values were recorded. Analyses on the role of soil water in controlling tree sap flux showed that $D$ and $R$ may be more influential than soil moisture even in climates with seasonal drought, as in parts of temperate Central Europe (Gebauer 2010), when time scales of days to weeks are considered.

\section{Conclusion}

This study in a species-rich tropical forest with perhumid climate in Central Sulawesi, Indonesia, shows that speciesspecific measurements of xylem flux density can provide insights into the role of tree size and environmental factors controlling tree water consumption. All seven tree species studied revealed convergent patterns in the regulation of sap flow, in that atmospheric vapour pressure deficit was the principal controlling environmental factor and $\mathrm{DBH}$ the dominant size attribute when the fluxes were analysed on a daily basis. Estimated daily stand transpiration was low in comparison to other tropical forest. We explained these low transpiration rates due to permanently high air humidity and extended periods of leaf wetness.

The Fagaceae $C$. acuminatissima diverges from the other species by a less tight coupling of daily xylem flux density to the vapour pressure deficit increase in the course of the day. Moreover, this species, which is abundant in the study area with phylogenetic relationships to extratropical genera, showed significantly higher sap flow and daily water consumption rates than the other coexisting species which is partly a consequence of the large height size Castanopsis trees can reach. 
Acknowledgements This study took place as part of the Collaborative Research Centre SFB 552 on the stability of rainforest margins in Indonesia (STORMA). We gratefully acknowledge the financial support granted by the German Science Foundation (DFG). We thank Heinz Coners and Hilmar Müller for technical support during the installation, Heike Culmsee for tree species identification, Wolfram Lorenz for organising the logistics in Palu, and our Indonesian counterparts and field assistants for their support.

Open Access This article is distributed under the terms of the Creative Commons Attribution Noncommercial License which permits any noncommercial use, distribution, and reproduction in any medium, provided the original author(s) and source are credited.

\section{References}

Andrade JL, Meinzer FC, Goldstein G, Holbrook NM, Cavelier J, Jackson P, Silvera K (1998) Regulation of water flux through trunks, branches, and leaves in trees of a lowland tropical forest. Oecologia 115:463-471

Becker P (1996) Sap flow in Bornean heath and dipterocarp forest trees during wet and dry periods. Tree Physiol 16:295-299

Clearwater MJ, Meinzer FC, Andrade JL, Goldstein G, Holbrook NM (1999) Potential errors in measurement of nonuniform sap flow using heat dissipation probes. Tree Physiol 19:681-687

Culmsee H, Leuschner C, Moser G, Pitopang R (2010) Forest aboveground biomass along an elevational transect in Sulawesi, Indonesia and the role of Fagaceae in tropical montane rain forests. J Biogeogr 37:960-974

Dietz J, Hölscher D, Leuschner Ch, Hendrayanto (2006) Rainfall partitioning in relation to forest structure in differently managed montane forest stands in Central Sulawesi, Indonesia. For Ecol Manag 237:170-178

Dietz J, Leuschner Ch, Hölscher D, Kreilein H (2007) Vertical patterns and duration of surface wetness in an old-growth tropical montane rainforest, Indonesia. Flora 202:111-117

Dünisch O, Morais RR (2002) Regulation of xylem sap flow in an evergreen, a semi-deciduous, and a deciduous Meliaceae species from the Amazon. Trees 16:404-416

Fetcher N, Oberbauer SF, Chazdon RL (1994) Physiological ecology of trees, shrubs, and herbs at La Selva. In: McDade LA, Bawa KS, Hespenheide HA, Hartshorn GS (eds) La Selva: ecology and natural history of a neotropical rainforest. University of Chicago Press, Chicago, pp 128-141

Gebauer T., 2010. Water turnover in species-rich and species-poor deciduous forests: xylem sap flow and canopy transpiration. Biodiversity and Ecology Series 4. Göttingen Centre for Biodiversity and Ecology. Göttingen, Germany. 136 p.

Goldstein G, Andrade JL, Meinzer FC, Holbrook NM, Jackson P, Cavelier J, Celis A (1998) Stem water storage and diurnal patterns of water use in tropical forest trees. Plant Cell Environ 21:397-406

Granier A (1985) Une nouvelle methode pour la mesure du flux de seve brute dans le tronc des arbres. Ann For Sci 42:193-200

Granier A, Huc R, Colin F (1992) Transpiration and stomatal conductance of two rain forest species growing in plantations (Simarouba amara and Goupia glabra) in French Guyana. Ann Sci For 49:17-24

Granier A, Huc R, Barigah ST (1996) Transpiration of natural rain forest and its dependence on climatic factors. Agric For Meteorol 78:19-29

Hertel D, Moser G, Culmsee H, Erasmi S, Horna V, Schuldt B, Leuschner Ch (2009) Below- and above-ground biomass and net primary production in a palaeotropical natural forest (Sulawesi, Indonesia) as compared to neotropical forests. For Ecol Manag 258:1904-1912

Holdridge LR, Grenke WC, Hatheway WH, Liang T, Tosi JA (1971) Forest environments in tropical life zones: a pilot study. Pergamon Press, Oxford, p 747

James SA, Meinzer FC, Goldstein G, Woodruff D, Jones T, Restom T, Mejia M, Clearwater M, Campanello P (2003) Axial and radial water transport and internal water storage in tropical forest canopy trees. Oecologia 134:37-45

Jimenez SM, Nadezhdina N, Čermák J, Morales D (2000) Radial variation in sap flow in five laurel forest tree species in Tenerife, Canary Islands. Tree Physiol 20:1149-1156

Jordan CF, Kline JR (1977) Transpiration of trees in a tropical rainforest. J Appl Ecol 14:853-860

Kelliher FM, Köstner BMM, Hollinger DY, Byers JN, Hunt JE, McSeveny TM, Meserth R, Weir PL, Schulze E-D (1992) Evapouration, xylem sap flow, and tree transpiration in a New Zealand broad-leaved forest. Agric For Meteorol 62:53-73

Meinzer FC (2003) Functional convergence in plant response to the environment. Oecologia 134:1-11

Meinzer FC, Goldstein G, Andrade JL (2001) Regulation of water flux through tropical forest canopy trees: do universal rules apply? Tree Physiol 21:19-26

Meinzer FC, James SA, Goldstein G, Woodruff D (2003) Whole-tree water transport scales with sapwood capacitance in tropical forest canopy trees. Plant Cell Environ 26:1147-1155

Meinzer FC, James SA, Goldstein G (2004) Dynamics of transpiration, sap flow and use of stored water in tropical forest canopy trees. Tree Physiol 24:901-909

Meinzer FC, Bond BJ, Warren JM, Woodruff DR (2005) Does water transport scale universally with tree size? Funct Ecol 19:558565

Motzer T, Munz N, Küppers M, Schmitt D, Anhuf D (2005) Stomatal conductance, transpiration and sap flow of tropical montane rain forest trees in the Southern Ecuadorian Andes. Tree Physiol 25:1283-1293

O'Brien JJ, Oberbauer SF, Clark DB (2004) Whole tree xylem sap flow response to multiple environmental variables in a wet tropical forest. Plant Cell Environ 27:551-567

Parolin P, Müller E, Junk WJ (2008) Sapwood area in seven common tree species of Central Amazon floodplains. Area Pesquisas Bot 59:277-286

Phillips N, Oren R, Zimmermann R (1996) Radial patterns of xylem sap flow in non-, diffuse- and ring-porous tree species. Plant Cell Environ 19:983-990

Phillips N, Oren R, Zimmermann R, Wright SJ (1999) Temporal patterns of water flux in trees and lianas in a Panamanian moist forest. Trees 14:116-123

Phillips NG, Ryan MG, Bond BJ, McDowell NG, Hinckley TM, Čermák J (2003) Reliance on stored water increases with tree size in three species in the Pacific Northwest. Tree Physiol 23:237245

Tyree MT, Ewers FW (1996) Hydraulic architecture of woody tropical plants. In: Mulkey SS, Chazdon RL, Smith AP (eds) Tropical forest plant ecophysiology. Chapman and Hall, New York, pp 217-243

Van Straaten O (2010)Drought effects on soil carbon dioxide efflux in two ecosystems in Central Sulawesi. Indonesia. PhD thesis. University of Göttingen, Germany. 86p

Zeppel MJB, Murray BR, Barton C, Eamus D (2004) Seasonal responses of xylem sap velocity to D and solar radiation during drought in a stand of native trees in temperate Australia. Funct Plant Biol 31:461-470 